\title{
Reversible intramolecular photocycloaddition of a bis(9-anthrylbutadienyl)paracyclophane - an inverse photochromic system. (Photoactive cyclophanes 5)
}

\author{
Henning Hopf ${ }^{*}, 1$, Christian Beck ${ }^{1}$, Jean-Pierre Desvergne ${ }^{2}$, \\ Henri Bouas-Laurent ${ }^{*}, 2$, Peter G. Jones ${ }^{3}$ and Ludger Ernst ${ }^{4}$
}

\section{Full Research Paper}

Address:

${ }^{1}$ Institut für Organische Chemie, Technische Universität Braunschweig, Postfach 3329, D-38023 Braunschweig, Germany, ${ }^{2}$ ISM, CNRS UMR 5255, Université Bordeaux 1, F-33405 Talence Cedex, France, ${ }^{3}$ Institut für Anorganische Chemie, Technische Universität Braunschweig, Postfach 3329, D-38023 Braunschweig, Germany and ${ }^{4}$ NMR-Laboratorium der Chemischen Institute der Technischen Universität Braunschweig, Hagenring 30, D-38106 Braunschweig, Germany

\section{Email:}

Henning Hopf ${ }^{*}$ - h.hopf@tu-bs.de; Jean-Pierre Desvergne -

jp.desvergne@ism.u-bordeaux1.fr; Henri Bouas-Laurent ${ }^{*}$ -

h.bouaslaurent@cegetel.net; Peter G. Jones - p.jones@tu-bs.de;

Ludger Ernst - I.ernst@tu-bs.de

* Corresponding author

Keywords:

anthracenes; cyclophanes; inverse photochromism;

photocycloaddition

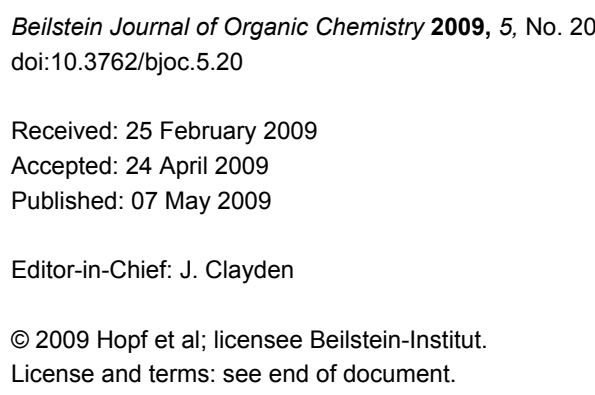

\begin{abstract}
The title compound, 4,13-bis[(1E,3E)-4-(9-anthracenyl)buta-1,3-dienyl][2.2]paracyclophane (2), prepared in 35\% overall yield from [2.2]paracyclophane, absorbs light at $\lambda_{\max }=400 \mathrm{~nm}$ with a tail down to $480 \mathrm{~nm}$. By irradiation into this band, 2 generates a single photoproduct, $\mathbf{4}$, whose absorption maximum is situated at $306 \mathrm{~nm}$. The starting material is recovered by irradiation at 306 $\mathrm{nm}$ or by heating. This 'inverse' photochromic system has a potential for optical information storage, compound $\mathbf{4}$ being stable in visible light, at ambient temperature.
\end{abstract}

\section{Introduction}

Photochromism [1], see Figure 1, is currently an active field of research as reflected in the literature [2-6] and finds commercial applications in the domain of reversible optical density materials. Diverse systems are under study for information storage and optical switches [7-9]. The majority of established systems show a 'positive' photochromism in which the elec- 
tronic absorption spectrum of the product $\mathrm{P}$ is red-shifted [1]. When the electronic absorption spectrum of $\mathrm{P}$ is blue-shifted, the photochromism is said to be 'negative' or 'inverse' [1].

Ftarting
material
$\begin{aligned} & \text { Figure 1: Schematic representation of a photochromic system. The } \\ & \text { reverse reaction can be a photochemical or thermal process. A and } \mathrm{P} \\ & \text { have different absorption spectra. }\end{aligned}$

Inverse photochromism is encountered in photoaddition of conjugated systems [10-17] and may be interesting for information storage materials because the photoproducts can be operated in visible light. Inverse photochromism was recently observed for some vinylogs of cinnamophanes [18,19], such as compound 1 (Figure 2). Several cycles were recorded but the photoproduct could not so far be isolated.

It occurred to us that the performance of these systems could be improved by incorporating the anthracene substrate, well known for its ability to generate definite photodimers [10-15], in the pseudo-gem positions of the cyclophane acting as a convenient scaffold, as demonstrated previously $[18,19]$. To avoid steric crowding and excessive distance between the chromophores, it seemed reasonable to select the rigid all-trans butadienyl tether as represented in compound $\mathbf{2}$ (see Figure 3 ).

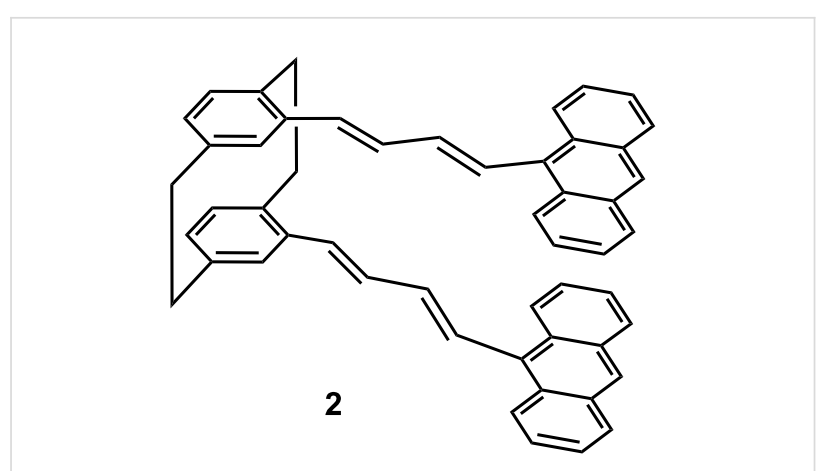

Figure 3: Molecular structure of 4,13-bis[(1E,3E)-4-(9-anthracenyl)buta-1,3-dienyl][2.2]paracyclophane (2).

The synthesis, molecular structure and photochromic properties of $\mathbf{2}$ are reported in this paper.

\section{Results and Discussion \\ 1 Synthesis}

Compound $\mathbf{2}$ was prepared from dialdehyde $\mathbf{3}$ using the Wittig reaction, as outlined in Scheme 1, in 48\% yield. Dialdehyde 3 wasobtained in five steps from [2.2]paracylophane, a commercial product, in $72 \%$ overall yield as described previously [19]. Therefore, the overall yield of $\mathbf{2}$ from the parent cyclophane was found tobe $35 \%$ on the gram scale.

The Wittig reaction provides a mixture of cis and trans isomers, but the pure all-trans isomer was isolated by crystallization as orange crystals (see Experimental). 9-(anthrylmethyl)triphen-
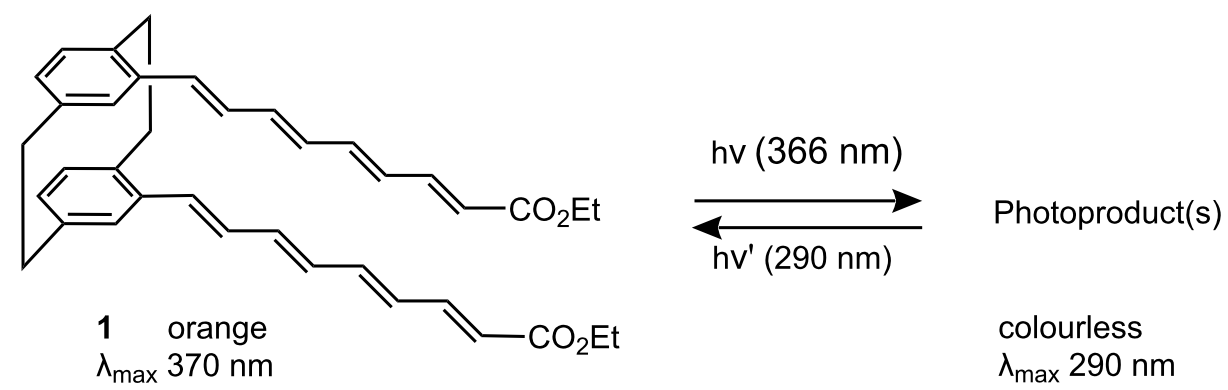

Figure 2: Photochromic reaction of pseudo-gem disubstituted tetraene [2.2]cyclophane 1 in acetonitrile, conc. $5 \times 10^{-4} \mathrm{M}$.

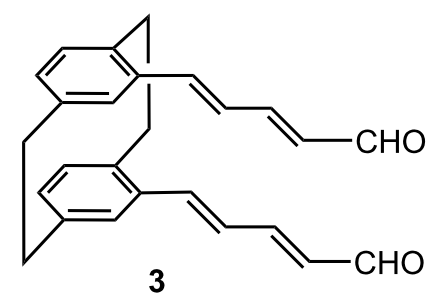

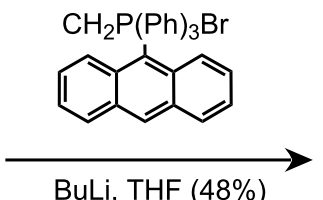

BuLi, THF (48\%)
2

(orange colour)

Scheme 1: Preparation of 2 (last step), using the Wittig reaction. The preparation of 3 has been described in ref [19]. 
ylphosphonium bromide was easily obtained from triphenylphosphine and 9-bromomethylanthracene.

\section{$2 \mathrm{X}$-ray structure analysis}

Single crystals suitable for X-ray structure determination were grown by slow evaporation of a solution of $2(150 \mathrm{mg})$ in dichloromethane $(10 \mathrm{~mL})$ by diffusion of pentane vapour. The molecular structure of $\mathbf{2}$ is presented in Figure 4.

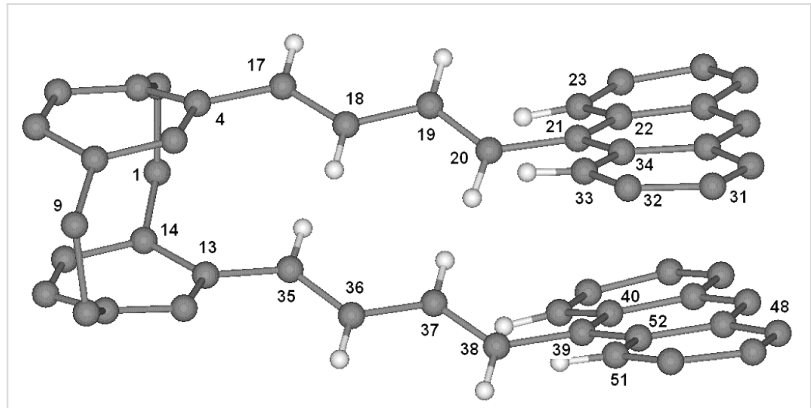

Figure 4: Molecular structure of $\mathbf{2}$ in the crystal. Radii are arbitrary; only selected $\mathrm{H}$ atoms are shown.

The double bonds are clearly all-trans and their average planes form twist angles with the two anthracene nuclei of $47^{\circ}$ and $44^{\circ}$,respectively; the two ethylenic systems are also not parallel to each other but subtend twist angles of $42-43^{\circ}$ (see Table 1). Finally, the interplanar angle between the two anthracene substrates is ca $4.5^{\circ}$ (Table 1). Consequently, the inter-ring distance varies between 3.40 and $3.80 \AA$. Two lateral anthracene nuclei are thus in close proximity (see Figure 5), in which two carbons are separated by the van der Waals distance, C31C48 (ca. $3.40 \AA$ ); two other carbons are also very close to each other: C32-C51 (ca. $3.65 \AA$ ). These remarkable features suggest preferred sites of reactivity inasmuch as this rigid geometry is not disfavoured in solution.

\section{Electronic absorption spectra and photo- chemistry}

\subsection{Electronic absorption spectra}

The electronic absorption spectra of $\mathbf{2}$ in methylcyclohexane $(\mathrm{MCH})$ and acetonitrile are represented in Figure 6. One notes

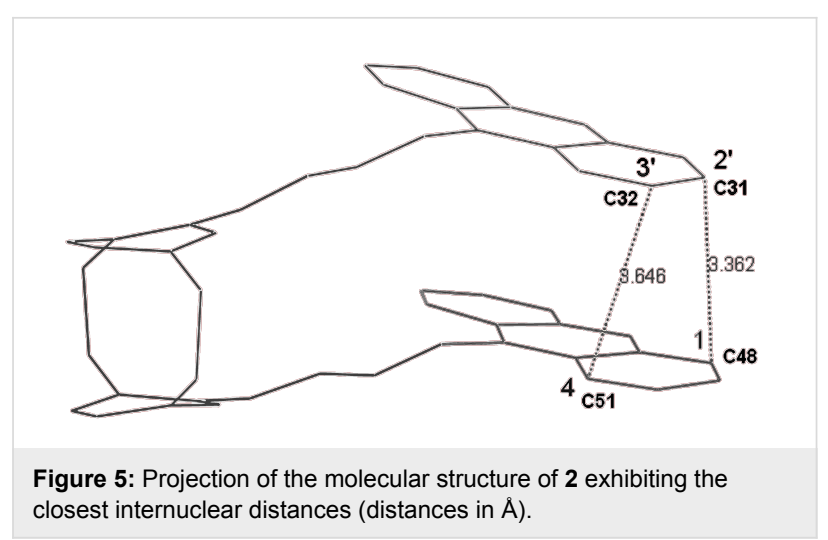

that the lowest energy band $\left(\lambda_{\max }=400 \mathrm{~nm}\right.$ with a tail down to $480 \mathrm{~nm}$ ) is clearly red-shifted as compared to those of all the cinnamophane vinylogs studied so far $[18,19]$, including compound $1\left(\lambda_{\max }=370 \mathrm{~nm}\right)$. The presence of the twisted butadienyl system introduces several torsional vibrations about the pseudo single bonds and attenuates the fine structure usually observed for anthracene derivatives (see Figure 6). The difference between the two solutions is thought to reflect some charge transfer in the more polar solvent, affecting the intensity balance but not the wavelength maxima.

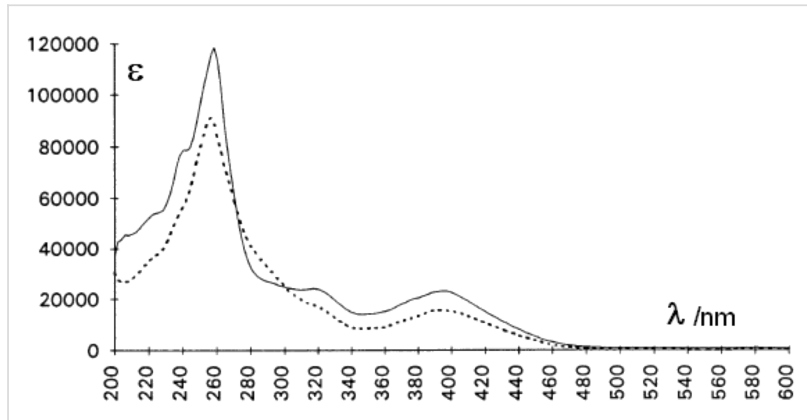

Figure 6: Electronic absorption spectra of 2 (conc. ca $10^{-4} \mathrm{M}$ ) in $\mathrm{MCH}$ (full line) and $\mathrm{CH}_{3} \mathrm{CN}$ (dotted line) at $20^{\circ} \mathrm{C}$.

\subsection{Irradiation}

Compound 2 was irradiated in acetonitrile in a quartz cell, at $400 \mathrm{~nm}$ (selected with a monochromator) using a Xenon lamp. Nitrogen was bubbled through the solution to prevent photoox-

Table 1: Angles between various partial planes in molecule 2 in the crystal.

$\begin{array}{cc}\text { torsion angles } & \mathrm{C} 19-\mathrm{C} 20-\mathrm{C} 21-\mathrm{C} 22 \\ & 47.1^{\circ} \\ \text { interplanar angles } & \mathrm{C} 17-\mathrm{C} 20 / \mathrm{C} 21-\mathrm{C} 34 \\ & 41.6^{\circ} \\ \text { deviation from parallelism } & \text { butadienes } \mathrm{C} 17-\mathrm{C} 20 / / \mathrm{C} 35-\mathrm{C} 38\end{array}$

$9^{\circ}$

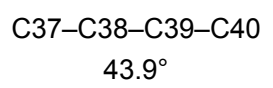

$4.5^{\circ}$ 
idation, and the spectra were recorded at various time intervals (Figure 7). Three isosbestic points at 220, 289, and $329 \mathrm{~nm}$ were observed as well as new absorptions at $306 \mathrm{~nm}$ and in the far UV. Similar features were noted for the $\mathrm{MCH}$ solutions. At that concentration, no intermolecular reaction could compete with an intramolecular process [12].

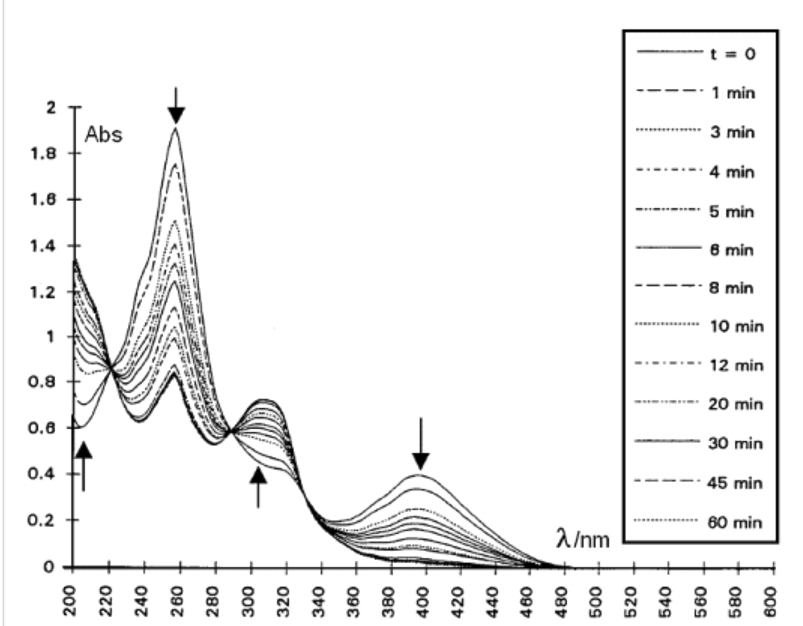

Figure 7: Irradiation of $2\left(2.6 \times 10^{-5} \mathrm{M}\right)$ in $\mathrm{CH}_{3} \mathrm{CN}$ at $400 \mathrm{~nm}$ at $20^{\circ} \mathrm{C}$. The spectra were recorded at various time intervals within $60 \mathrm{~min}$. The arrows point to the maxima.

Disappearance quantum yields at $394 \mathrm{~nm}$ were found to be low in methylcyclohexane $\left(1.5 \times 10^{-4}\right)$ and in acetonitrile $\left(4.2 \times 10^{-2}\right)$. The weakness of the cyclophotoaddition probably reflects a preference for internal conversion among the diverse deactivation channels of the $S_{1}$ state. The clear difference between the two media may result from an electron transfer between the two anthracene nuclei in the more polar solvent, as demonstrated in previous work [20]. The ion pair can accelerate a closure reaction involving a donor and an acceptor partner, such as a Diels-Alder reaction (see below).

\subsection{Photodissociation}

Under the same experimental conditions, the photoproduct 4 was irradiated at $306 \mathrm{~nm}$ for 10 min until the starting material spectrum was recovered (Figure 8). Disappearance quantum yield of 4 at $306 \mathrm{~nm}$ was found to be $1.6 \times 10^{-1}$ for both solvents.

\subsection{Photochromic cycles}

Using the preceding dilute solution in a quartz cell and the same setup, the medium was alternatively irradiated at $400 \mathrm{~nm}$ and at $306 \mathrm{~nm}$ in both solvents, and the absorbance measured at 392 $\mathrm{nm}$ at each cycle. The results are represented for $\mathrm{MCH}$ solution in Figure 9. One observes a drop of $50 \%$ absorbance after 8 cycles for $\mathrm{MCH}$ and 5 cycles for $\mathrm{CH}_{3} \mathrm{CN}$ (not shown).

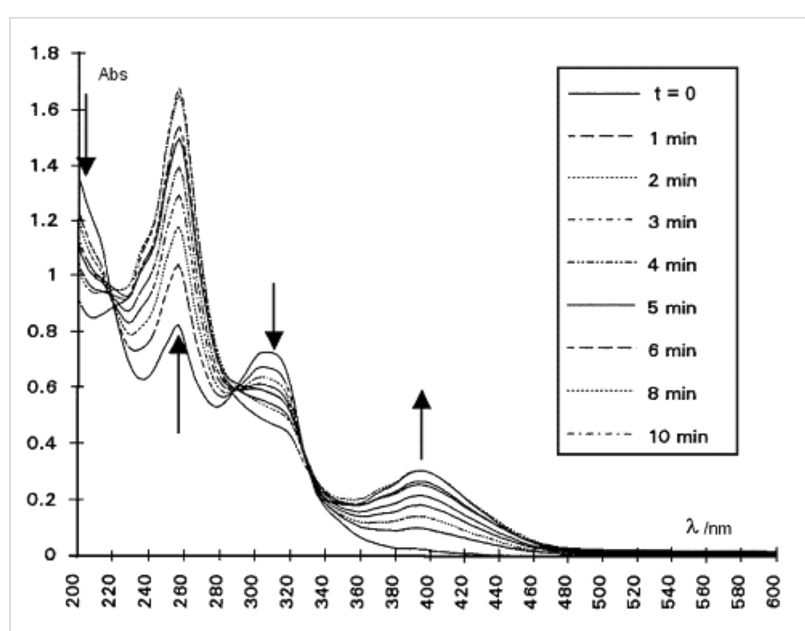

Figure 8: Irradiation at $306 \mathrm{~nm}$ of the photoproduct $\mathbf{4}$ obtained at 400 $\mathrm{nm}$ in the same setup; the spectra were recorded at various time intervals, within $10 \mathrm{~min}$, at ambient temperature.

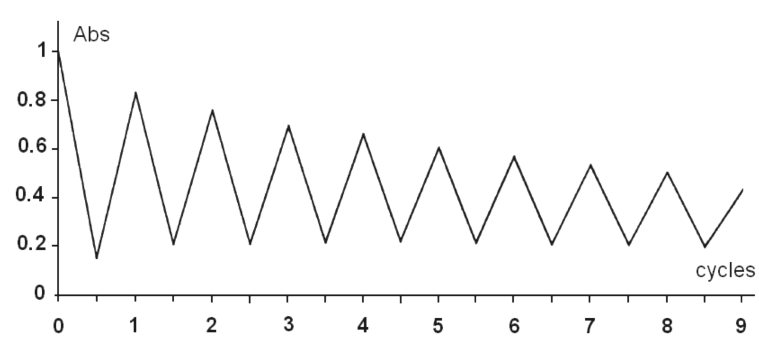

Figure 9: Reversibility of the formation of the photoproduct 4 at 400 $\mathrm{nm}(40 \mathrm{~min})$ and photodissociation of 4 at $306 \mathrm{~nm}$ in $\mathrm{MCH}$.

The photolysis at $306 \mathrm{~nm}$ must involve one or several photoreactions leading to products transparent at $392 \mathrm{~nm}$. Thermal dissociation (a retro Diels-Alder reaction, see below) was expected to exhibit a quantitative yield as shown hereafter. The photoproduct 4, prepared and isolated as described below, was heated at $55{ }^{\circ} \mathrm{C}$ in $\mathrm{CDCl}_{3}$. The dissociation was evaluated with time by following the intensity change of the characteristic $\delta=$ $4.73 \mathrm{ppm}$ signal (see spectrum below) until complete extinction (see Supporting Information p S2). The dissociation kinetics were found to be first order with a half-life of ca $3.8 \mathrm{~h}$. This suggests a much longer lifetime at ambient temperature, as observed experimentally.

\section{Structure of the photoproduct}

Preparative irradiation of a solution of 2 in $\mathrm{CH}_{2} \mathrm{Cl}_{2}$ through which nitrogen was bubbled with a medium pressure mercury lamp in a Pyrex photoreactor (UV light filtered by $\mathrm{NaNO}_{2}$ aqueous solution) gave 4 as a white powder after a week at -20 ${ }^{\circ} \mathrm{C}$. That a single photoproduct was produced is borne out by HPLC, showing the increase of a single peak at the expense of 
the starting material (see Supporting Information p S3). No melting point could be determined because the powder decomposes back to $\mathbf{2}$ on heating. The mass spectrum was found to be that of 2 (see Experimental). Single crystals suitable for X-ray structure analysis could not be obtained. Evidence for the structure rests on the electronic absorption spectrum and the NMR spectral data. The UV spectrum clearly shows the disappearance of the $350-450 \mathrm{~nm}$ absorption band, indicating that the anthryl groups have reacted. The new band with a maximum at $306 \mathrm{~nm}$ suggests the formation of substituted naphthalenes [21], but because the disubstituted cyclophane also absorbs in that region [22], it is difficult to get more precise information.

The ${ }^{1} \mathrm{H}$ NMR (Figure 10 and Supporting Information $\mathrm{p} \mathrm{S}$ ) and the ${ }^{13} \mathrm{C}$ NMR spectra (52 distinct signals are observed, see Experimental) point to the absence of symmetry in the molecule. This rules out symmetrical cycloadditions such as the $9,9^{\prime}: 10,10^{\prime}[4+4]$ reaction of anthracenes [11], whether combined or not with two cyclobutane-forming [2+2]additions. Dissymmetrical closures [11,12] such as $1,4: 9^{\prime}, 10^{\prime}[4+4]$ or 1,4 : 2',3'[4+2]cycloadditions (as well as rearranged products) are thus to be considered. A deeper analysis of the experimental data follows.

${ }^{13}$ C NMR data: The molecular formula includes 52 carbon atoms; among the 52 signals observed, 16 are due to quaternary
C (132 to $142 \mathrm{ppm}), 28$ to $\mathrm{CH}$ (121.3 to 140.4), 4 to other $\mathrm{CH}$ likely corresponding to bridgehead carbons (54.9 to $66.0 \mathrm{ppm}$ ) and finally 4 to $\mathrm{CH}_{2}$ (31.6 to $36.5 \mathrm{ppm}$ ), attributable to the ethanocyclophane bridges.

In previously studied cyclophanes, the cyclobutane rings exhibited ${ }^{13} \mathrm{C}$ signals between 42 and $51 \mathrm{ppm}[18,19]$. No such signals are apparent in the present case; therefore it is proposed that no reaction has occurred between the ethylenic bonds. This statement is borne out by the observation of the ${ }^{1} \mathrm{H}$ NMR spectrum.

1H NMR data: The spectrum exhibits three regions at the following chemical shifts: $7.62-5.97 \mathrm{ppm}(28 \mathrm{H})$ corresponding to aromatic and ethylenic protons; $3.8-2.5 \mathrm{ppm}$, corresponding to aliphatic protons $(10 \mathrm{H})$ and a prominent signal at $4.73 \mathrm{ppm}(2 \mathrm{H}$, broad singlet) attributable also to aliphatic protons. Compared to $\mathbf{2}$, there are four new signals corresponding to aliphatic protons, in keeping with the cycloadduct pictured in Figure 11.

This is a Diels-Alder adduct resulting from the reaction of the 1,4 positions ( $\mathrm{C} 41$ and $\mathrm{C} 44$ ) of one nucleus and the $2^{\prime}, 3^{\prime}$ positions of the other nucleus (C24 and C25). The structure of $\mathbf{4}$ is further supported by the ${ }^{1} \mathrm{H}_{-}{ }^{1} \mathrm{H}$ COSY spectrum (see Supporting Information p S4).
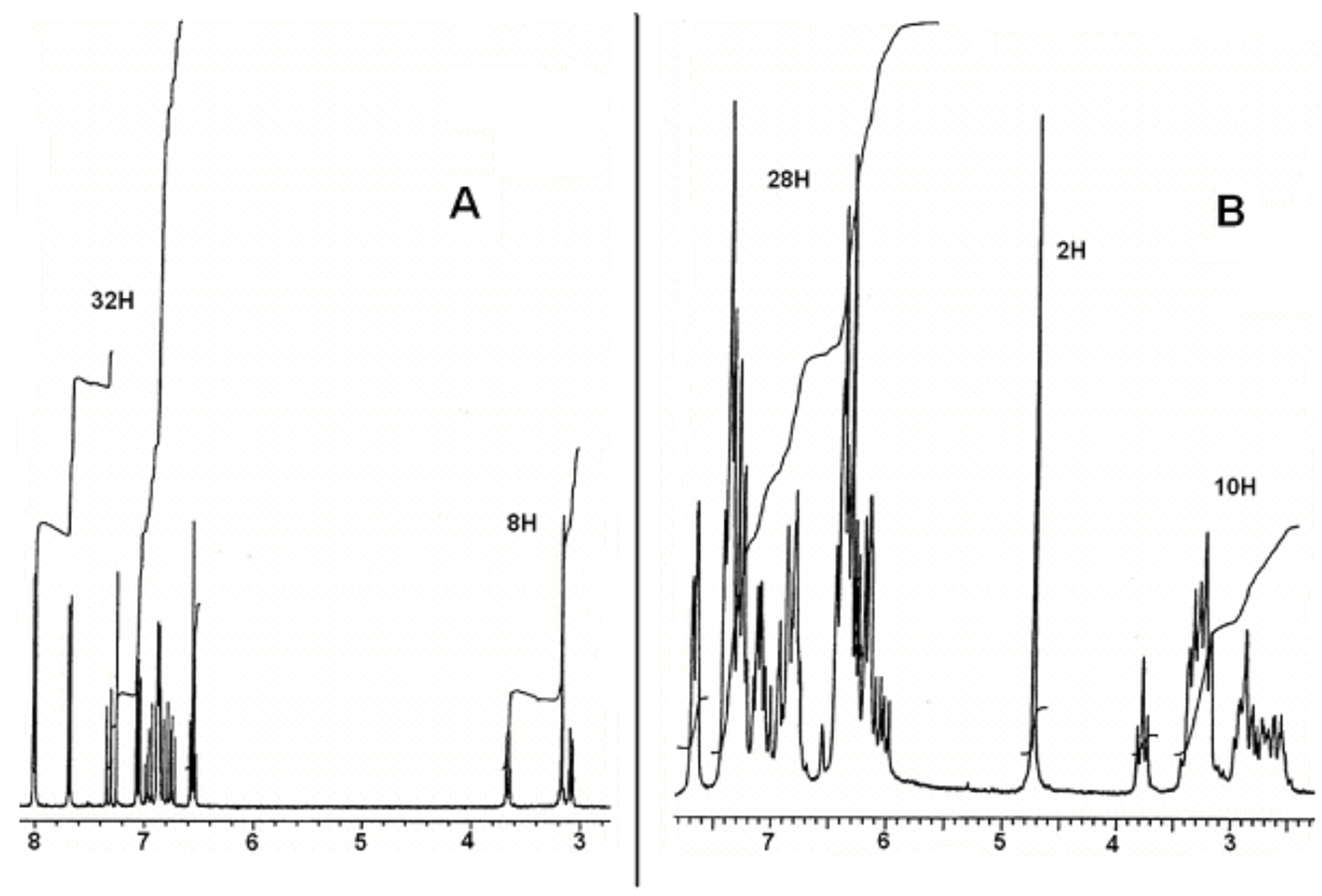

Figure 10: ${ }^{1} \mathrm{H}$ NMR spectra $(400 \mathrm{MHz}, \mathrm{CDCl} 3)$. A: Compound 2, B: Compound 4 


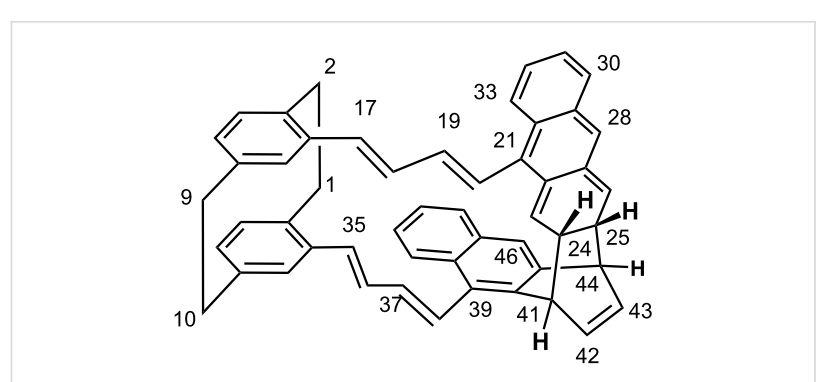

Figure 11: Proposed structure of 4 (1,4 : 2',3'-cycloadduct).

It indicates that the signal at $\delta=3.8$ (pseudotriplet) is coupled with that at $\delta=3.2$ and that at $\delta=6.05$, whereas the signal at 3.2 is coupled with those at $\delta=3.8$ and $6.38 \mathrm{ppm}$, respectively. The signals at 3.2 and $3.8 \mathrm{ppm}$ can be attributed to allylic bridgehead $\mathrm{H} 24$ and $\mathrm{H} 25$, coupled with the vicinal ethylenic hydrogen atoms (23 and 26) at 6.05 and $6.38 \mathrm{ppm}$. Bridgehead protons $\mathrm{H} 41$ and $\mathrm{H} 44$ then display the peak at $\delta=4.73 \mathrm{ppm}$, reflecting a very small coupling with their neighbours $\left(\mathrm{H}-\mathrm{C}-\mathrm{C}-\mathrm{H}\right.$ dihedral angles close to $\left.90^{\circ}\right)[23,24]$.

The majority of anthracene derivatives are known to undergo a $[4+4]$ cycloaddition from the $S_{1}$ state $[11,12]$, but some [4+2]cycloadditions were observed to occur under geometrical constraints $[11,12,24]$ through a triplet state process [25]. [4+2]Cycloadditions can take place in a hot ground state [26]. This result is reminiscent of the [4+2]-photocycloaddition between two naphthalene substrates for the anti-[2.2](1,4)-naphthalenophane leading to dibenzoequinine, a stable polycyclic molecule [27]. In that case, the first Diels-Alder addition is immediately followed by a second, because of the superimposition of the newly formed diene and the ene centres (cascade reaction). This is not possible in the present situation, considering Figure 11 The non-reactivity of the ethylenic bonds is understandable as the reaction affects first the anthracene substrates leading to $\mathbf{4}$ in which the double bonds are no longer at mutual distances conducive to further reactions. Such a 1,4:2',3'-cyclophotoaddition between two anthracene nuclei is unprecedented.

\section{Summary and Conclusion}

The target molecule (dianthryl-butadienyl[2.2]paracyclophane 2) was synthesized and shown to possess the anticipated photochromic properties. The two interconverting forms exhibit good thermal stability. The cycloreversion can be induced by irradiation or by heating. Because of its slow response and the fatigue observed in the photodissociation, this system does not seem suitable as a switch, but might be considered for applications such as optical storage [28], owing to the large spectral shift $\left(\Delta \widetilde{v}_{\max }\right.$ ca $\left.7500 \mathrm{~cm}^{-1}\right)$ of the electronic absorption spectra between $2\left(\lambda_{\max } 400 \mathrm{~nm}\right)$ and $4\left(\lambda_{\max } 306 \mathrm{~nm}\right)$ and the stability of the photoproduct in interior daylight.

\section{Experimental General Techniques}

Melting Points (up to $200{ }^{\circ} \mathrm{C}$ ) were taken with a Büchi 510 Melting Point Appararus. Those above $200{ }^{\circ} \mathrm{C}$ were measured with a Kofler Heiztischmikroskop Thermopan (Reichert); all m.p. are uncorrected. HPLC was performed using a Nucleosil $100-7$ octadecyl phase (Macherey Nagel, Düren, No 715802) column, with a pump L-6200 and a photodiode array detector L-3000 (Hitachi). Column chromatography: Merck Kieselgel 60 (70-230 mesh). Thin layer chromatography: Kieselgel (Merck) or Alox (Macherey-Nagel). Elemental Analyses were obtained by the Institute of Inorganic and Analytical Chemistry and of Pharmaceutical Chemistry of the Technical University of Braunschweig.

\section{Spectrometry}

NMR spectra were recorded with an AC-200 $\left({ }^{1} \mathrm{H}: 200 \mathrm{MHz}\right.$, $\left.{ }^{13} \mathrm{C}: 50 \mathrm{MHz}\right)$ or an AM-400 $\left({ }^{1} \mathrm{H}: 400 \mathrm{MHz},{ }^{13} \mathrm{C}: 100 \mathrm{MHz}\right)$ Bruker apparatus. The chemical shifts were measured with tetramethylsilane as internal reference. The ${ }^{1} \mathrm{H}_{-}{ }^{1} \mathrm{H}$ COSY spectrum was used to interpret the spectrum of 4 , and the DEPT technique to assign the class of carbon atoms in the ${ }^{13} \mathrm{C}$ spectra. The IR spectra were recorded with a Nicolet 320 FT spectrometer. Mass spectra were performed with a Finnigan MAT 8430 spectrometer using the classical Electron Ionization at 70 $\mathrm{eV}$ or the FAB technique, respectively. Electronic absorption spectra were recorded with a HP 8542 A-Diode Array or a Hitachi UV 3300 spectrometer. The samples were weighed with a Mettler UM3 balance (sensitivity $10^{-7} \mathrm{~g}$ ).

\section{Quantum yields}

Reaction quantum yields were determined as described elsewhere [29], using the Parker iron trioxalate actinometer. The monochromatic beams were obtained from a cooled $1000 \mathrm{~W}$ Xenon lamp, using a Bausch and Lomb monochromator. The samples were previously purged of oxygen with an argon or nitrogen stream.

\section{Preparations}

1. 4,13-bis[(1E,3E)-4-(9-anthracenyl)-buta-1,3-dienyl][2.2]paracyclophane (2):

In a $250 \mathrm{~mL}$, dried round-bottom flask, equipped with a reflux condenser, a Claisen adapter, a stirring system, and degassed with nitrogen, $1.3 \mathrm{~g}$ dialdehyde $(4.1 \mathrm{mmol})$ was dissolved in $50 \mathrm{~mL}$ absolute THF. In another vessel, $6.56 \mathrm{~g}$ (12.3 $\mathrm{mmol})$ of 9 -anthryltriphenylphosphoniumbromide, in suspension in 50 $\mathrm{mL}$ THF under nitrogen, was mixed with a solution of $8.2 \mathrm{~mL}$ BuLi (1.5 M, hexane). The resulting deep red solution was introduced dropwise with a needle into the dialdehyde solution and the reaction medium was stirred overnight at ambient 
temperature. Finally, the reaction mixture was hydrolyzed with crushed ice/water. The crude product was filtered off, dissolved in a small volume of $\mathrm{CH}_{2} \mathrm{Cl}_{2}$ and dried over $\mathrm{MgSO}_{4}$. After adding $3 \mathrm{~g}$ of silica gel to the filtered solution, the solvent was distilled off under reduced pressure and the residue was eluted on a $100 \mathrm{~g}$ silica gel column with $1.5 \mathrm{~L}$ of pentane and then a pentane $/ \mathrm{CH}_{2} \mathrm{Cl}_{2}$ : 4/1 mixture. Compound 2 (1.83 g) was obtained as a mixture of cis/trans isomers. The solid was dissolved in about $200 \mathrm{~mL}$ of $\mathrm{CH}_{2} \mathrm{Cl}_{2}$ in an ultrasonic bath, with gentle warming. To this solution was added about $500 \mathrm{~mL}$ of pentane and the flask was cooled to $-20{ }^{\circ} \mathrm{C}$. After two days, a precipitate of fine crystals appeared, which were filtered off and carefully washed with pentane. After drying under high vacuum, $1.32 \mathrm{~g}$ (1.99 mmol, 48\% yield) of all-trans 2 was isolated as an orange microcrystalline powder. $-\mathrm{R}_{\mathrm{f}}\left(\mathrm{SiO}_{2}\right.$; pentane/ $\left.\mathrm{CH}_{2} \mathrm{Cl}_{2}: 2 / 1\right): 0.41 ; \mathrm{mp} 217{ }^{\circ} \mathrm{C}$; $-{ }^{1} \mathrm{H}-\mathrm{NMR}\left(400 \mathrm{MHz}, \mathrm{CDCl}_{3}\right.$, $\left.25^{\circ} \mathrm{C}, \mathrm{TMS}\right): \delta=8.00$ (s, $\left.2 \mathrm{H} ; 28-\mathrm{H}, 46-\mathrm{H}\right), 8.00$ (br-d, ${ }^{3} J(\mathrm{H}, \mathrm{H})$ $=8.4 \mathrm{~Hz}, 4 \mathrm{H} ; 26-\mathrm{H}, 30-\mathrm{H}, 44-\mathrm{H}, 48-\mathrm{H}), 7.68\left(\mathrm{br}-\mathrm{d},{ }^{3} J(\mathrm{H}, \mathrm{H})=\right.$ $8.4 \mathrm{~Hz}, 4 \mathrm{H}$; 23-H, 33-H, 41-H, 51-H), $7.32\left(\mathrm{~d},{ }^{3} J(\mathrm{H}, \mathrm{H})=15.7\right.$ Hz, $2 \mathrm{H}$; 20-H, 38-H), 7.05 (br-ps-t, ${ }^{3} J(\mathrm{H}, \mathrm{H})=8.4 \mathrm{~Hz}, 4 \mathrm{H}$, 24-H, 32-H, 42-H, 50-H), $6.96\left(\mathrm{dd},{ }^{3} J(\mathrm{H}, \mathrm{H})=15.3 \mathrm{~Hz},{ }^{3} J(\mathrm{H}, \mathrm{H})\right.$ $=10.4 \mathrm{~Hz}, 2 \mathrm{H} ; 18-\mathrm{H}, 36-\mathrm{H}), 6.87-6.81(\mathrm{~m}, 8 \mathrm{H} ; 5-\mathrm{H}, 12-\mathrm{H}$, 17-H, 35-H, 25-H, 31-H, 43-H, 49-H), $6.75\left(\mathrm{dd},{ }^{3} J(\mathrm{H}, \mathrm{H})=15.7\right.$ $\left.\mathrm{Hz},{ }^{3} J(\mathrm{H}, \mathrm{H})=10.4 \mathrm{~Hz}, 2 \mathrm{H} ; 19-\mathrm{H}, 37-\mathrm{H}\right), 6.57\left(\mathrm{~d},{ }^{3} J(\mathrm{H}, \mathrm{H})=\right.$ $7.8 \mathrm{~Hz}, 2 \mathrm{H} ; 8-\mathrm{H}, 15-\mathrm{H}), 6.53\left(\mathrm{dd},{ }^{3} J(\mathrm{H}, \mathrm{H})=7.8 \mathrm{~Hz},{ }^{4} J(\mathrm{H}, \mathrm{H})=\right.$ $1.7 \mathrm{~Hz}, 2 \mathrm{H}$; 7-H, 16-H), 3.67-3.64 (m, $2 \mathrm{H}$; 1a-H, 2a-H), 3.17 (s, $4 \mathrm{H}$; 9-H, 10-H), 3.09-3.06 ppm (m, $2 \mathrm{H} ; 1 \mathrm{~b}-\mathrm{H}, 2 \mathrm{~b}-\mathrm{H})$; ${ }^{13} \mathrm{C}-\mathrm{NMR}\left(100 \mathrm{MHz}, \mathrm{CDCl}_{3}, 25{ }^{\circ} \mathrm{C}, \mathrm{TMS}\right): \delta=139.5(\mathrm{qC})$, $138.1(\mathrm{CH}), 137.7(\mathrm{qC}), 134.9(\mathrm{CH}), 132.3(\mathrm{CH}), 131.7(\mathrm{CH})$, $131.1(\mathrm{qC}), 130.1(\mathrm{CH}), 129.8(\mathrm{CH}), 129.0(\mathrm{qC}), 128.2(\mathrm{CH})$, $126.0(\mathrm{CH}), 125.3(\mathrm{CH}), 124.8(\mathrm{CH}), 124.5(\mathrm{CH}), 35.1\left(\mathrm{CH}_{2}\right)$, $32.8 \mathrm{ppm}\left(\mathrm{CH}_{2}\right) ;-\mathrm{MS}(70 \mathrm{eV}): m / z(\%)=664(78)\left[\mathrm{M}^{+}\right], 473$ (15) $\left[\mathrm{M}^{+}-191\right], 332$ (23) $\left[\mathrm{C}_{8} \mathrm{H}_{7} \mathrm{CHCHCHCH}-\mathrm{A}^{+}\right], 331$ (43) $\left[\mathrm{C}_{26} \mathrm{H}_{19}{ }^{+}\right], 315$ (24), 215 (25), 203 (34), 191 (100) $\left[\mathrm{A}-\mathrm{CH}_{2}^{+}\right]$; $\mathrm{UV} / \mathrm{Vis}\left(\mathrm{CH}_{3} \mathrm{CN}\right): \lambda_{\max }(\lg \varepsilon)=256$ (4.96), 320 (sh) (4.23), 372 (sh) (4.07), $392 \mathrm{~nm}$ (4.19); - UV/Vis (methylcyclohexane): $\lambda_{\max }(\lg \varepsilon)=218(\mathrm{sh})(4.71), 240(\mathrm{sh})(4.90), 258$ (5.07), 316 (4.38), $396 \mathrm{~nm}$ (4.36); - IR (KBr): $\widetilde{v}=3019 \mathrm{~cm}^{-1}(\mathrm{~m}), 2923$ (m), $1621(\mathrm{w}), 1441(\mathrm{w}), 1407(\mathrm{w}), 994(\mathrm{~s}), 950(\mathrm{~m}), 880(\mathrm{~s})$, 839 (m), 779 (m), 730 (vs), 717 (m); - HRMS (FAB): m/z calcd: 664.313001 , found: $664.313 \pm 3 \mathrm{ppm}$; Elemental analysis: calcd C 93.94, H 6.06, found C 91.74, H 6.03.

2. Photoproduct 4: A solution of $133 \mathrm{mg}(0.2 \mathrm{mmol})$ of $\mathbf{2}$ in 200 $\mathrm{mL}$ of $\mathrm{CH}_{2} \mathrm{Cl}_{2}$, carefully degassed by bubbling nitrogen through it, was irradiated at $\lambda>400 \mathrm{~nm}$ for $2 \mathrm{~h}$ with a high pressure mercury lamp in a Pyrex photoreactor. The cooling tube of the latter was filled with a $\mathrm{NaNO}_{2}$ solution $(75 \mathrm{~g} / \mathrm{L})$ maintaining the reaction medium at $10-20{ }^{\circ} \mathrm{C}$. After the end of irradiation, the solution was concentrated at ca $15^{\circ} \mathrm{C}$ to $10 \mathrm{~mL}$; then $25 \mathrm{~mL}$ pentane was added and the medium allowed to stand at $-20^{\circ} \mathrm{C}$ for a week. A white precipitate appeared, which was filtered off and washed with pentane. After desiccation under high vacuum, 4 was isolated (71 mg: $0.11 \mathrm{mmol}, 53 \%)$. From the mother liquor, some additional powder was collected and identified as the starting material 2 . The irradiation was followed by HPLC monitoring after 30, 90, and $120 \mathrm{~min}$ (see Supporting Information p S3). $\mathrm{R}_{\mathrm{f}}\left(\mathrm{Alox} ; \mathrm{CH}_{2} \mathrm{Cl}_{2}\right.$ ): 0.49. mp. dec. by heating; ${ }^{1} \mathrm{H}-\mathrm{NMR}$ (400 MHz, $\left.\mathrm{CDCl}_{3}, 25^{\circ} \mathrm{C}, \mathrm{TMS}\right): \delta=7.62-7.58$ (m, 2 H), 7.38-7.17 (m, 8 H), 7.08-6.95 (m, 2 H), 6.93-6.67 (m, 4 $\mathrm{H}), 6.40-6.20(\mathrm{~m}, 9 \mathrm{H}), 6.13\left(\mathrm{dd},{ }^{3} J(\mathrm{H}, \mathrm{H})=7.6 \mathrm{~Hz},{ }^{3} J(\mathrm{H}, \mathrm{H})=\right.$ $11.8 \mathrm{~Hz}, 1 \mathrm{H}), 6.08$ (br-s, $1 \mathrm{H}), 5.97\left(\mathrm{dd},{ }^{3} J(\mathrm{H}, \mathrm{H})=8.7 \mathrm{~Hz}\right.$, $\left.{ }^{3} J(\mathrm{H}, \mathrm{H})=14.8 \mathrm{~Hz}, 1 \mathrm{H}\right) 4.65$ (br-s, $\left.2 \mathrm{H}\right), 3.70$ (ps-t, ${ }^{3} J(\mathrm{H}, \mathrm{H})=$ $8.3 \mathrm{~Hz}, 1 \mathrm{H}), 3.32-3.08(\mathrm{~m}, 5 \mathrm{H}), 2.87-2.75 \mathrm{ppm}(\mathrm{m}, 4 \mathrm{H})$; ${ }^{13} \mathrm{C}-\mathrm{NMR}\left(100 \mathrm{MHz}, \mathrm{CDCl}_{3}, 25{ }^{\circ} \mathrm{C}, \mathrm{TMS}\right): \delta=142.0(\mathrm{qC})$, $141.6(\mathrm{qC}), 140.5(\mathrm{qC}), 140.4(\mathrm{CH}), 139.9(\mathrm{qC}), 139.4(\mathrm{qC})$, $139.2(\mathrm{qC}), 138.6(\mathrm{qC}), 137.6(\mathrm{qC}), 137.1(\mathrm{qC}), 137.0(\mathrm{qC})$, $136.6(\mathrm{qC}), 136.1(\mathrm{CH}), 136.0(\mathrm{qC}), 135.8(\mathrm{qC}), 135.71(\mathrm{qC})$, $135.67(\mathrm{qC}), 135.6(\mathrm{CH}), 135.0(\mathrm{CH}), 134.3(\mathrm{CH}), 133.3(\mathrm{CH})$, $132.0(\mathrm{qC}), 131.5(\mathrm{CH}), 130.8(\mathrm{CH}), 130.5(\mathrm{CH}), 129.9(\mathrm{CH})$, $129.8(\mathrm{CH}), 128.6(\mathrm{CH}), 128.32(\mathrm{CH}), 128.28(\mathrm{CH}), 128.2$ $(\mathrm{CH}), 126.7(\mathrm{CH}), 126.5(\mathrm{CH}), 125.4(\mathrm{CH}), 125.35(\mathrm{CH})$, $125.32(\mathrm{CH}), 125.1(\mathrm{CH}), 125.0(\mathrm{CH}), 124.8(\mathrm{CH}), 124.5(\mathrm{CH})$, $124.0(\mathrm{CH}), 123.9(\mathrm{CH}), 121.5(\mathrm{CH}), 121.3(\mathrm{CH}), 66.0(\mathrm{CH})$, $56.2(\mathrm{CH}), 55.0(\mathrm{CH}), 54.9(\mathrm{CH}), 36.5\left(\mathrm{CH}_{2}\right), 36.3\left(\mathrm{CH}_{2}\right), 35.4$ $\left(\mathrm{CH}_{2}\right), 31.6 \mathrm{ppm}\left(\mathrm{CH}_{2}\right)$. The mass spectrum was found to be identical to that of compound 2 .

\section{X-Ray structure determination of $\mathbf{2} \cdot 1 / 2 \mathrm{CH}_{2} \mathrm{Cl}_{2}$}

Crystal data: $\mathrm{C}_{52.5} \mathrm{H}_{41} \mathrm{Cl}, \mathrm{Mr}=707.30$, monoclinic, $\mathrm{P} 2{ }_{1} / \mathrm{c}, \mathrm{T}=$ $-100{ }^{\circ} \mathrm{C}, \mathrm{a}=17.716(3), \mathrm{b}=10.236(2), \mathrm{c}=21.811(3) \AA, \beta=$ $110.523(8)^{\circ}, \mathrm{U}=3704.1 \AA^{3}, \mathrm{Z}=4, \mathrm{~F}(000)=1492, \lambda\left(\mathrm{Mo} \mathrm{K}_{\alpha}\right)=$ $0.71073 \AA, \mu=0.14 \mathrm{~mm}^{-1}, \mathrm{D}_{\mathrm{X}}=1.268 \mathrm{~g} \mathrm{~cm}^{-3}$. Data collection: A yellow lath ca. $0.9 \times 0.2 \times 0.1 \mathrm{~mm}$ was mounted in inert oil on a glass fibre and transferred to the cold gas stream of a Siemens P4 diffractometer. Data were recorded to $2 \theta 50^{\circ}$. Structure refinement: The structure was refined using SHELXL-97 [30]. Hydrogen atoms were included using a riding model. The dichloromethane molecule is disordered across an inversion centre. Restraints to light atom $U$ values were applied. The final wR2 (all reflections) was 0.124 for 6369 intensities, 491 parameters and 516 restraints, with $\mathrm{R} 1(\mathrm{I}>2 \sigma(\mathrm{I}))$ 0.052 ; S 0.77, max. $\Delta \rho 0.31$ e $\AA^{-3}$. See also Supporting Information $\mathrm{p} \mathrm{S} 5$.

X-ray crystallographic data (excluding structure factors) were deposited under the number CCDC-717774 and can be obtained free of charge from the Cambridge Crystallographic Data Centre via www.ccdc.cam.ac.uk/data_request/cif. 


\section{Supporting Information}

\section{Supporting Information File 1}

Thermal dissociation of photoproduct 4, HPLC diagram of the photochemical preparation of $4,{ }^{1} \mathrm{H}-{ }^{1} \mathrm{H}-\mathrm{COSY}$ spectrum of photoproduct $\mathbf{4}$, and other crystal data for $\mathbf{2}$.

[http://www.beilstein-journals.org/bjoc/content/ supplementary/1860-5397-5-20-S1.doc]

\section{Acknowledgments}

We thank the Fonds der Chemischen Industrie for the continuous support of our work. The Université Bordeaux 1, $C N R S$, and the Région Aquitaine are thanked for financial support.

This paper is dedicated to Dr. Esther Oliveros on occasion of her $60^{\text {th }}$ birthday.

\section{References}

1. Bouas-Laurent, H.; Dürr, H. Pure Appl. Chem. 2001, 73, 639-665. doi:10.1351/pac200173040639

2. Brown, G. H., Ed. Photochromism; Wiley-Interscience: New York, 1971.

3. Dürr, H.; Bouas-Laurent, H., Eds. Photochromism, Molecules and Systems, 2nd ed.; Elsevier: Amsterdam, 2003.

4. McArdle, C. B., Ed. Applied Photochromic Polymer Systems; Blackie: Glasgow and London, 1992.

5. Crano, J. C.; Guglielmetti, R., Eds. Organic Photochromic and Thermochromic Compounds; Plenum: New York, 1999; Vol. $1 \& 2$.

6. Kume, S.; Nishihara, H. Dalton Trans. 2008, 3249-3364.

7. Irie, M. Chem. Rev. 2000, 100, 1683-1716. doi:10.1021/cr980068| (Special issue on Memories and Switches).

8. Feringa, B. L., Ed. Molecular Switches; Wiley-VCH: Weinheim, 2001.

9. Raymo, F. M.; Tomasulo, M. Chem.-Eur. J. 2006, 12, 3186-3193. doi:10.1002/chem. 200501178

10. Inverse photochromism: in ref [3], chapters 12-15.

11. Bouas-Laurent, H.; Castellan, A.; Desvergne, J.-P.; Lapouyade, R. Chem. Soc. Rev. 2000, 29, 43-55. doi:10.1039/a801821i

12. Bouas-Laurent, H.; Castellan, A.; Desvergne, J.-P.; Lapouyade, R. Chem. Soc. Rev. 2001, 30, 248-263. doi:10.1039/b006013p

13. Coursan, M.; Desvergne, J.-P.; Deffieux, A. Macromol. Chem. Phys. 1996, 197, 1599-1608. doi:10.1002/macp.1996.021970502

14. Desvergne, J.-P.; Bouas-Laurent, H.; Deffieux, A. Mol. Cryst. Liq. Cryst. 1994, 246, 111-118. doi:10.1080/10587259408037797

15. Bouas-Laurent, H.; Desvergne, J.-P. In Photochemical Key Steps in Organic Synthesis; Mattay, J.; Griesbeck, A., Eds.; VCH, 1994; pp 308-311.

16. Ikegami, M.; Oshiro, I.; Arai, T. Chem. Commun. 2003, 1566-1567. doi:10.1039/b304034h

17. Fukaminato, T.; Tanaka, M.; Kuroki, L.; Irie, M. Chem. Commun. 2008, 3924-3926. doi:10.1039/b804137g

18. Greiving, H.; Hopf, H.; Jones, P. G.; Bubenitschek, P.; Desvergne, J.-P.; Bouas-Laurent, H. Eur. J. Org. Chem. 2005, 558-566. doi:10.1002/ejoc.200400592
19. Hopf, H.; Greiving, H.; Beck, C.; Dix, I.; Jones, P. G.; Desvergne, J.-P.; Bouas-Laurent, H. Eur. J. Org. Chem. 2005, 567-581. doi:10.1002/ejoc.200400596

20. Dvornikov, A. S.; Desvergne, J.-P.; Oulianov, D. A.; Bouas-Laurent, H.; Rentzepis, P. M. Helv. Chim. Acta 2001, 84, 2520-2532. doi:10.1002/1522-2675(20010919)84:9<2520::AID-HLCA2520>3.0.CO ;2-4

21. Friedel, R. A.; Orchin, M. UV Spectra of Aromatic Compounds; J. Wiley: New York, 1951; Vol. 1, pp 1-339.

22. Greiving, H.; Hopf, H.; Jones, P. G.; Bubenitschek, P.; Desvergne, J.-P.; Bouas-Laurent, H. Liebigs Ann. 1995, 1949-1956. doi:10.1002/jlac.1995199511274

23. Hesse, M.; Meier, H.; Zeeh, B. Spektroskopische Methoden in der organischen Chemie; Thieme Verlag: Stuttgart, 1995.

24. Becker, H.-D.; Sandros, K.; Andersson, K. Angew. Chem., Int. Ed. Engl. 1983, 22, 495-496. doi:10.1002/anie.198304951

25. Becker, H.-D.; Andersson, K. Tetrahedron Lett. 1985, 26, 6129-6132. doi:10.1016/S0040-4039(00)95105-0

26. Michl, J.; Bonačic-Koutecky, V. Electronic Aspects of Organic Photochemistry; Wiley-Interscience: New York, 1990; pp $94 \mathrm{ff}$.

27. Wasserman, H. H.; Keehn, P. M. J. Am. Chem. Soc. 1967, 89, 2770-2772. doi:10.1021/ja00987a068

28. Dvornikov, A. S.; Bouas-Laurent, H.; Desvergne, J.-P.; Rentzepis, P M. J. Mater. Chem. 1999, 9, 1081-1084. doi:10.1039/a808272c

29. Castellan, A.; Desvergne, J.-P.; Bouas-Laurent, H. Nouv. J. Chim. 1979, 3, 231-237.

30. Sheldrick, G. M. Acta Crystallogr., Sect. A 2008, 64, 112-122. doi:10.1107/S0108767307043930

\section{License and Terms}

This is an Open Access article under the terms of the Creative Commons Attribution License (http://creativecommons.org/licenses/by/2.0), which permits unrestricted use, distribution, and reproduction in any medium, provided the original work is properly cited.

The license is subject to the Beilstein Journal of Organic Chemistry terms and conditions:

(http://www.beilstein-journals.org/bjoc)

The definitive version of this article is the electronic one which can be found at: doi:10.3762/bjoc.5.20 